\title{
Coronavirus Disease (COVID-19) with Special Reference to Pakistan: A Review on its Different Aspects
}

\author{
Sahar Mubashar*, Tariq Mukhtar and Nasir Ahmad Khan \\ Department of Plant Pathology, Pir Mehr Ali Shah Arid Agriculture University \\ Rawalpindi, Pakistan
}

\begin{abstract}
A B S T R A C T
The novel coronavirus took the whole world by storm and in no time spread across the globe and claimed many lives. The most affected countries of the world are USA, Brazil, India, Italy, Iran, Spain, Russia, South Africa, United Kingdom and Peru. In Pakistan, the pilgrims from Iran became the major source of spread of the virus in the country, as the Government did not impose quarantine measures to restrict their movement. In Pakistan, the most affected province was Sindh followed by Punjab, Khyber Pakhtunkhwa and Balochistan. According to WHO, the most common symptoms are fever, dry cough, sore throat, fatigue and diarrhea and shortness of breath in severe cases. The virus attacks throat, lungs and trachea converting them to virus factories to infect more cells. It attacks not only lungs but also other vital organs of the body like kidneys and heart. It is spread from human to human through respiratory droplets or direct contact. Moreover, there have been reports of the mixed infection of coronavirus with other bacteria, fungi and viruses. Various methods are used for the detection of the virus such as nucleic acid and immunological methods but RT-PCR is considered as the most reliable. Some antiviral drugs have shown to be effective against the virus like Favilavir, Remdesivir, Chloroquine, hydroxy-chloroquine, Tocilizumab etc. but further clinical studies are required to confirm their efficacy. In Pakistan, blood plasma therapy is in high demand but involves the risk of transmission of blood borne pathogens. As Pakistan lacks medical facilities. the government has to get testing kits and primers from other countries. Only few quarantine centers are available and there is shortage of drugs, beds, trained doctors and paramedical staff. Unfortunately, no vaccine is available yet so the only management strategy is the prevention of infection by wearing masks and following social distancing. Cleanliness, hygiene and quarantine measures are the key to stop any epidemic to pandemic and is known to human being throughout the history and it becomes more critical when global travelling is a norm.
\end{abstract}

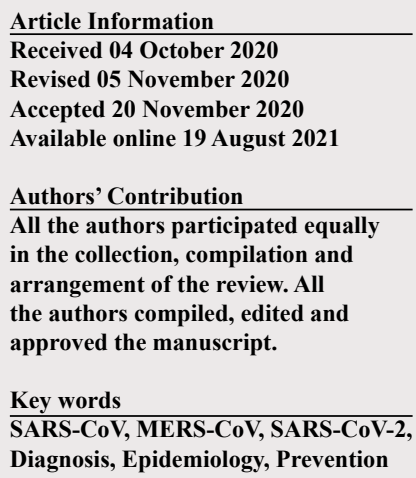

\section{INTRODUCTION}

C oronavirus belongs to the family Coronaviridae of the order Nidovirales which includes two genera i.e. Coronavirus and Torovirus. Coronaviruses belong to the type species "Infectious bronchitis virus" (Cavanagh, 1997). So far there have been three coronaviruses of zoonotic nature, SARS-CoV-1 (severe acute respiratory syndrome coronavirus), MERS-CoV (Middle East respiratory syndrome coronavirus), and SARS-CoV-2 (severe acute respiratory syndrome coronavirus-2). SARSCoV-1 was first reported in China in 2002, infected 8089 people of seven continents within no time and took 774 lives (de Wit et al., 2016). Similarly, MERS-CoV spread across the seven continents infecting 2500 people and claimed

\footnotetext{
* Corresponding author: sahar_mubashir@live.com 0030-9923/2021/0005-1947 \$ 9.00/0

Copyright 2021 Zoological Society of Pakistan
}

858 lives (de Wit et al., 2016). In December 2019, Wuhan city of Hubei province of China witnessed pneumonia cases of unknown origin and etiology (Riou and Althaus, 2020). Later, on $7^{\text {th }}$ of January, 2020, Chinese authorities confirmed it as novel coronavirus 2019 (2019-nCoV) (WHO, 2020a). This novel coronavirus took the whole world by storm and in no time spread across many borders with globally confirmed cases of 21,294,845 and 761,779 deaths as per World Health Organization (WHO) Situation Report-209 of $16^{\text {th }}$ of August, 2020 (WHO, 2020b). The International Committee on the Taxonomy of Viruses named this novel coronavirus (2019-nCoV) as severe acute respiratory syndrome 2 (SARS-CoV-2). Since it is a matter of global health concern, WHO declared it as a pandemic on $11^{\text {th }}$ of March, 2020 (Whitworth, 2020). In Pakistan, confirmed initial cases of coronavirus were reported on $26^{\text {th }}$ of February, 2020 by the Federal Health Minister, one in Karachi and the other in Islamabad, both of them were traced back to the travel history of Iran (Ali, 
2020). In about 15 days, the number of Covid-19 positive cases reached to 20; 14 cases in Sindh, 5 in Gilgit Baltistan and a 12-year-old child in Balochistan (Waris et al., 2020).

Since Pakistan shares it borders with China and Iran (the epicenters of pandemic) and have good relationship with both the countries. Increase rate of travel and trade with China and due to religious associations with Iran, every year about 0.7 million Pakistani pilgrims visit Iran. These travellers were the major cause of spread of Covid-19 disease in Pakistan. Out of 7000 pilgrims returned from Iran, 1433 were tested positive (Anonymous, 2020a). Authorities took it easy and did not impose strict quarantine measures to restrict the movements of people crossing the borders. These pilgrims became the source of spread across the country. Due to rapid increase in the number of cases, the only option to prevent the spread of the disease was by implementing social distancing using lockdown. Government imposed a countrywide lockdown on $24^{\text {th }}$ of March, 2020 for more than a month. The confirmed cases of coronavirus in Pakistan were 295,849 and there were 6,294 deaths (OCHA, 2020). At present, no vaccine is available for coronavirus, so imposing strict quarantine measures and social distancing are the only available ways to prevent the spread of disease.

\section{VIRUS AND ITS CHARACTERISTICS}

Although the exact source of origin of 2019 novel coronavirus is still unknown, it is assumed that it may be linked to Huanan seafood market in Wuhan where live animals like snakes, bats, frogs etc. are sold (Zhang et al., 2020a). Viral-like pneumonia symptoms were initially observed in some of the people who visited the super market which suggested animals as the initial source of the spread of novel coronavirus into humans. Later on, it was also diagnosed in the people having no connection or exposure to the seafood market which revealed human to human transmission. The first infected patients acquired the virus from animals which explains that the novel coronavirus is a virus of zoonotic origin. Since SARS-CoV-2 genome shows $96 \%$ similarity with a bat coronavirus (BatCoV RaTG13) which shows that this novel coronavirus originated from bats (Zhou et al., 2020a). The intermediate hosts of SARS-CoV and MERS-CoV are camels and civets before transferring to humans (Cui et al., 2019). SARS-CoV and MERS-CoV have similarity with novel coronavirus so, it is believed that the 2019 novel coronavirus has been transmitted from unknown intermediate hosts or may be directly transmitted to humans (Zhou et al., 2020b, c).

Coronavirus is derived from the Latin word "corona" meaning crown because of the appearance of surface projections in a negatively stained electron micrographs of the members of coronavirus genus. It is a single stranded RNA virus. Virions are enveloped and spherical in shape, commonly $120-160 \mathrm{~nm}$ in diameter having around 65 $\mathrm{nm}$ internal icosahedral core shell and a helical nucleocapsid, containing nucleo-capsid protein N. Glycoproteins form large surface projections of coronaviruses like Spike Protein S, an integral Protein M, a small membrane protein $\mathrm{E}$ and a nucleo-capsid protein N. The ratio of S:E:M:N varies. The largest are spike proteins which range from 1160 to 1452 aa and can be cleaved into S1 and S2 subunits. S Protein is also responsible for cell attachment, membrane fusion, hemagglutination and inducing neutralizing antibodies. Challenges of coronavirus can be met by immunization with $\mathrm{S}$ protein that will induce protection to some coronaviruses (IBV, MHV, TGEV). The genome size of members of the order Nidovirales are $27.6-31 \mathrm{~kb}$ for Coronavirus and $25-30 \mathrm{~kb}$ for Torovirus respectively. The genome of the coronavirus is the largest viral RNA which is non-segmented. Complete genome sequences of several coronaviruses have been determined for example TGEV (Transmissible Gastroenteritis Virus), MHV (Mouse Hepatitis Virus), IBV (Infectious Bronchitis Virus), BCoV (Bovine Coronavirus), SARS-CoV, (severe acute respiratory syndrome coronavirus), $\mathrm{HCoV}-\mathrm{OC} 43$ (Human coronavirus OC43), and HCoV-229E (Human coronavirus 229 E) etc. (Anonymous, 2005). Nucleocapsid is enveloped and is formed by the combination of genomic RNA with $\mathrm{N}$ proteins. The $\mathrm{M}$ protein gives shape to the virus and $\mathrm{S}$ protein is used for entry into cells. They are present on the surface of the virus with a crown like appearance hence named coronavirus (Siu et al., 2008). Recognition of receptor plays an important role in the first step of viral infection. During entry into human cells, the SARS-CoV-2 S glycoprotein attaches with ACE-2 enzyme (human angiotensin converting enzyme 2 ) which is a cellular receptor. It is a trans-membrane protein and is expressed in heart, lungs, intestines, kidney and testis (Tipnis et al., 2000). The S protein consists of functional domain S1 and S2 that are important for binding with receptors and fusion of membranes (Zhang et al., 2014). On S2 domain, there is a receptor binding domain (RBD) which binds to angiotensin converting enzyme 2 receptor (ACE-2) an important factor that influences virus tropism (Kuo et al., 2000). Structural analysis shows that the binding affinity of SARS-CoV-2 with ACE-2 receptor is 10 times greater than SARS-CoV which suggests its efficient transmission in humans (Wrapp et al., 2020). After binding, capsid protein is released into the cytoplasm (Masters, 2006) after entering into cytoplasm un-coating of viral RNA starts and is translated into poly-proteins ppla and pplab respectively. The viral RNA acts as a 
template to form negative sense RNA which is then used to form positive sense RNA genomes. The assembling of virus takes place in the Endoplasmic Reticulum and Golgi apparatus and are transported to plasma membrane to release mature viruses (Siu et al., 2008; Masters, 2006).

\section{EPIDEMIOLOGY}

After the first outbreak of novel coronavirus 2019 in Wuhan, in December 2019 in Hubei province of China, the virus within few weeks spread throughout China and to other Asian countries, Africa, Middle Eastern countries, Americas, Europe and Oceania. Until $16^{\text {th }}$ of August, 2020 , there were $21,294,845$ positive cases with 761,779 deaths (WHO, 2020b). Till $21^{\text {st }}$ of August, 2020, the top most affected countries were USA $(n=5,746,534)$, Brazil $(n=3,505,097)$, India $(n=2,910,032)$, Russia $(n=946,976)$, South Africa $(\mathrm{n}=599,940)$, Peru $(\mathrm{n}=567,059)$. In Pakistan, total confirmed positive cases were 295,849 with 6,294 deaths and 280,682 recoveries up till $31^{\text {st }}$ of August, 2020 (OCHA, 2020). The death rate of the coronavirus was $2.1 \%$ and recovery rate was $93.8 \%$. The numbers of coronavirus cases from the date of its first report till August 2020 in the World and in Pakistan are given in Figures 1 and 2.

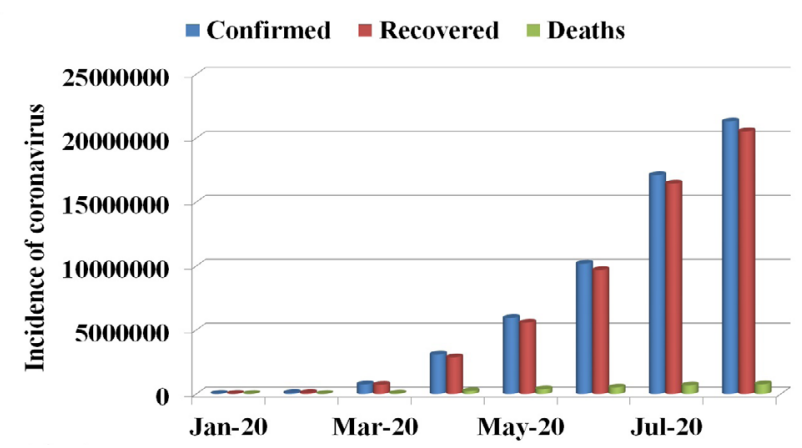

Fig. 1. Incidence of Coronavirus in the World from January 2020 to August 2020 according to WHO Situation Reports.

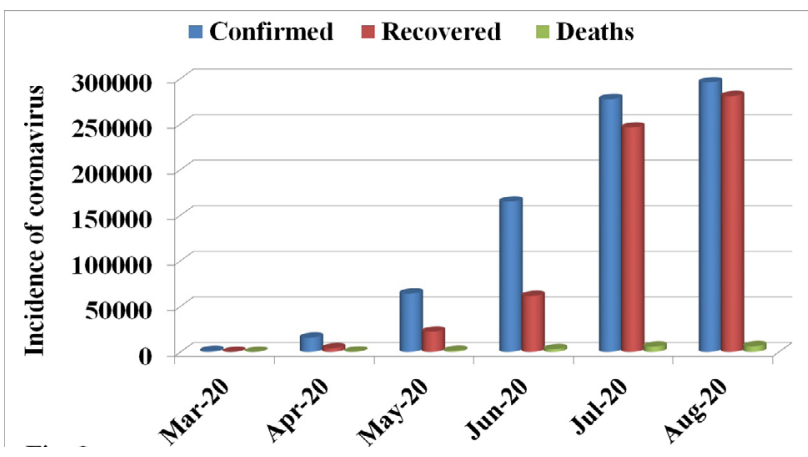

Fig. 2. Incidence of Coronavirus in Pakistan from $26^{\text {th }}$ of February, 2020 till August, 2020.
The situation of COVID-19 in different provinces of Pakistan from $26^{\text {th }}$ of February, 2020 to $21^{\text {st }}$ of August, 2020 is given in Table I according to Health Advisory Platform by Ministry of National Health Services Regulations and Coordination. The provinces of Sindh and Punjab were the most affected.

Table I. The situation of COVID-19 in different provinces of Pakistan from $26^{\text {th }}$ of February, 2020 to $21^{\text {st }}$ of August, 2020.

\begin{tabular}{llllll}
\hline Province & Cases & Deaths & $\begin{array}{l}\text { \% } \\
\text { Deaths }\end{array}$ & $\begin{array}{l}\text { Recover- } \\
\text { ies }\end{array}$ & $\begin{array}{l}\text { \%e- } \\
\text { covery }\end{array}$ \\
\hline Punjab & 95958 & 2188 & 2.28 & 90233 & 94.03 \\
Sindh & 127381 & 2350 & 1.84 & 120757 & 94.79 \\
KPK & 35545 & 1243 & 3.49 & 32893 & 92.53 \\
Baluchistan & 12424 & 139 & 1.11 & 11294 & 90.90 \\
AJK & 2223 & 61 & 2.74 & 2066 & 92.93 \\
GB & 2604 & 63 & 2.41 & 2235 & 85.82 \\
Islamabad & 15453 & 175 & 1.13 & 14101 & 91.25 \\
\hline
\end{tabular}

KPK, Khyber Pukhtunkhwa; AJK, Azad Jammu and Kashmir; GB, Gilgit Baltistan.

On the basis of data from the early outbreak in China from $10^{\text {th }}$ of January to $24^{\text {th }}$ of January, 2020, the trend of increase in incidence followed exponential growth. The reporting rate was increased from 2 to 8 folds and $\mathrm{R}_{\circ}$ (mean basic reproduction number) was found in the range from 2.24-3.58 (Zhao et al., 2020). Another data from $31^{\text {st }}$ of December, 2019 to $28^{\text {th }}$ of January, 2020 suggested similar results with $\mathrm{R}_{\circ}$ of 2.68 and epidemic doubling time of 6.4 days (Wu et al., 2020a, b). The reproduction rate of SARSCoV-2 ranged from 2.4 to 3.3 and these numbers varied according to mobility, quarantine measures, people at risk, susceptibility and other parameters. Therefore, we can say that every infected person could infect 2 to 3 people on average (Peiris et al., 2004; Zhu et al., 2020).

\section{SYMPTOMS AND TRANSMISSION}

If a person is infected by SARS-CoV-2, the symptoms normally appear after 5 to 6 days (Liu et al., 2020). However, in some cases, the incubation period is reported to be as long as 40 days with 14 days of median incubation period (Wang et al., 2020a). The incubation period of mild and severe cases may be different depending on the immune system and patient's age. This period appears to be shorter in the patients that are greater than 70 years which is about 11.5 days as compared to the patients which are less than 70 years in which the incubation period can be of 20 days (Wang et al., 2020a, b). The symptoms caused 
by COVID-19 are usually like normal cold and influenza and do not get severe. However, if a person is suffering from underlying conditions, the symptoms may get worse for example in cases of diabetes, heart and lung diseases. In such cases, patient can become critical and ultimately death can occur. Some people can have no symptoms at all. According to WHO reports, the most common symptoms of COVID-19 as observed in more than 70,000 cases in China were: Fever (88\%), dry cough and sore throat (68\%), fatigue $(38 \%)$, diarrhea (4\%) and were identical to SARS-CoV and MERS-CoV (Yang et al., 2020; Wang et al., 2020a). Moreover, it also caused shortness of breath in nearly $20 \%$ cases and sore throat and severe headache in $13 \%$ cases. This novel coronavirus normally attacks the respiratory system and can lead to severe respiratory distress, heart injury or bacterial infections (Chen et al., 2020a). The virus initially infects the lining of throat, lungs and tracheal cells, converting them into virus factories which produces huge amount of viruses that in turn infect more cells. The immune system then responds to the virus by sending signals to the body to produce cytokines and results in the feeling of general malaise and high temperature (Lei et al., 2020). In case of severe infection, the alveoli become filled with water and causes shortness of breath and coughing with thick mucus which contains the dead lung cells that are killed by SARS-COV-2. The coronavirus attack is not just limited to lungs but it also attacks other important organs of the body like kidneys and may cause organ failure (Li et al., 2020a, b). Fan et al. (2020) found that the virus binds to ACE-2 bearing cells which are highly expressed in the cells of lungs, kidneys and seminiferous ducts of testis and cause damage to them. The novel coronavirus destroys gastrointestinal bacteria and cause digestive problems like vomiting, diarrhea and loss of appetite (Zhang and $\mathrm{Zu}, 2020)$. Guo et al. (2020) reported that SARS-CoV-2 is transmitted among humans through respiratory droplets when a person coughs or sneezes, resulting in the pushing of droplets up to 3 feet. These droplets can be found on the upper surface of eyes, nose and mouth of adjacent person. It has also been reported in a recent study that ocular surface is able to carry and transmit SARS-CoV-2 infection (Lu et al., 2020). Other ways of spread of coronavirus are: hand shaking, contact with the virus infected surfaces or objects, repeatedly touching of eyes, nose, and mouth, or exposure to the infected patient's excreta. Chan et al. (2020) described another hidden mode of transmission of this virus unintentionally by asymptomatic virus carriers to close contacts.

\section{CLINICAL MANIFESTATIONS AND CO- INFECTION OF COVID-19}

Clinical investigations show great resemblance of SARS-CoV-2 with SARS-CoV-1 and MERS-CoV. About $81 \%$ of the cases were mild and recovered in two weeks (Wu and McGoogan, 2020). Severe cases result in ARDS (acute respiratory distress syndrome), septic shock and ultimately results in organ failure. Males were found to be more infected with SARS-CoV-2 as compared to females (Badawi and Ryoo, 2016) due to the role of sex hormones and $\mathrm{X}$ chromosomes in the adaptive immunity (Jaillon et al., 2019). In serological evidences of severe coronavirus infections, 30\% incidence of Chlamydophilla pneumonia and 9\% incidence of Mycoplasma pneumoniae were found (Zahariadis et al., 2006). Moreover, during SARS outbreak in Hong Kong, SARS and human metapneumovirus coinfection was also reported (Lee et al., 2007). The coinfection of MERS-CoV with tuberculosis and influenza has also been reported (Alfaraj et al., 2017a, b). All these factors indicate the co-infection of coronavirus with other respiratory pathogens. However, the studies are limited on this clinical phenomenon.

Table II. Comparison of symptoms caused by SARS-CoV, MERS-CoV and COVID-19.

\begin{tabular}{|c|c|c|c|}
\hline Diseases & Respiratory symptoms & Other symptoms & Chest-computed tomography scan(CT) \\
\hline Influenza & $\begin{array}{l}\text { Sore throat, dry cough, runny } \\
\text { and stuffy nose }\end{array}$ & $\begin{array}{l}\text { Muscle aches, malaise } \\
\text { and high fever }\end{array}$ & $\begin{array}{l}\text { Sub-pleural consolidation/peri bronchial distribution } \\
\text { Small patch GGO }\end{array}$ \\
\hline Common cold & Sneezing, runny and stuffy nose & No discomfort & Normal \\
\hline SARS-CoV-1 & Dyspnea an cough & $\begin{array}{l}\text { Fever with chills, ac- } \\
\text { companied with malaise } \\
\text { headache and diarrhea }\end{array}$ & $\begin{array}{l}\text { GGO sub-pleural, consolidation and noticeable lower } \\
\text { lobe association, interlobular septal and thickening }\end{array}$ \\
\hline MERS-CoV & Dyspnea, sore throat, dry cough & Fever with chills & $\begin{array}{l}\text { Joint/bilateral, sub-pleural air space, widespread GGO, } \\
\text { pleural-effusions and infrequent septal thickening. }\end{array}$ \\
\hline Mild COVID-19 & Sore throat, cough or no cough & Fever & Multifocal \& patchy GGO's, sub-pleural distribution \\
\hline $\begin{array}{l}\text { Severe COV- } \\
\text { ID-19 }\end{array}$ & $\begin{array}{l}\text { Breathlessness, and failure of } \\
\text { respiratory system }\end{array}$ & $\begin{array}{l}\text { Muscle ache, fever, } \\
\text { headache, confusion }\end{array}$ & GGO with diffused heterogeneous consolidation \\
\hline
\end{tabular}


Early detection of SARS-CoV-2 is important for the application of affective control measures but the possibility of SARS-CoV-2 co-infection should not be neglected. Zhou et al. (2020c) reported that out of 191 patients in China, $50 \%$ of the cases that did not survive had secondary infections. About 10 studies showed that co-infection of COVID-19 ranged from $0.6 \%$ to $45.0 \%$. Six studies described bacterial co-infections like Streptococcus pneumoniae, C. pneumoniae and eight studies disclosed viral co-infections like Influenza Virus A and Influenza Virus B. One COVID-19 patient with Aspergillus co-infection was also reported (Lescure et al., 2020). There is no characteristic information to distinguish co-infections of SARS-CoV-2 with other pathogens, so further microbiological assays and clinical studies are needed. Moreover, in laboratory findings, a substantial decrease in the number of lymphocytes in the infected patients were observed that can be used as an index in the detection of COVID-19. All these factors result because of the destruction of the immune cells and impairment of immune system (Chen et al., 2020a). More severe lymphopenia developed in case of non-survivors (Wang et al., 2020c).

\section{DIAGNOSIS OF COVID-19}

Because of the continuous and increasing spread of SARS-CoV-2, the global health community's most important challenge is the rapid and early detection of positive cases of SARS-CoV-2. Various detection methods are used to detect coronavirus such as nucleic acid and immunological methods or imaging techniques. Of all these techniques real time reverse transcriptase PCR (RTPCR) for the detection of viral RNA is considered the most appropriate and reliable technique. In this method sample is taken with the help of cotton swab from the nasopharyngeal and upper respiratory tract regions (Sethuraman et al., 2020). For the detection of coronavirus using PCR, the target genes are ORF $1 \mathrm{a}$ and $\mathrm{b}$ genes and $\mathrm{S}, \mathrm{E}, \mathrm{N} \mathrm{Rd} / \mathrm{Rp}$ respectively (Corman et al., 2020; Tang et al., 2020). According to Corman et al. (2020), the initial screening of coronavirus positive cases involved testing of target $\mathrm{E}$ as recommended by WHO using $\mathrm{Rd} / \mathrm{Rp}$ primers as two target assays which is considered as the most effective and efficient way of diagnosis. However, a false negative during RT-PCR may occur due to errors in sampling or untimely collection of samples (Sethuraman et al., 2020).

Immunological tests are conducted by measuring the quantity of antibodies produced as a result of host immune response to the coronavirus infection. It is reported that during the $2^{\text {nd }}$ and $3^{\text {rd }}$ week of SARS-CoV-2 infection, high levels of virus specific antibodies Immunoglobulin $\mathrm{G}$ (IgG) and Immunoglobulin M (IgM) are produced (Sethuraman et al., 2020). Furthermore, serological techniques like ELISA (Enzyme Linked Immunosorbent Assay) using IgG and IgM have been reported to be highly specific for the detection of COVID-19 (Xiang et al., 2020). In addition, chest computed tomography scan (CT) is also considered reliable method for the detection of COVID-19 (Li and Xia, 2020). Use of CT scan technique is however, limited to specific viral disease detection, but is efficient in the early detection and can be helpful to stop the transmission of a pandemic disease.

CT findings of COVID-19 showed that initially there was a small sub-pleural opacity that grew larger. Two weeks after the growth, lesions absorbed gradually resulting in the formation of sub-pleural parenchymal bands in the recovered patients. However, in the initial radiological findings, severe and non-severe cases were $23.9 \%$ and $5.2 \%$ respectively (Guan et al., 2020). Pakistan's scientific community is working in collaboration with health professionals and governments across the globe to find cure and management of the disease. Biological community of Pakistan helped health professionals to perform PCR for diagnosis. A team from NUST and Punjab University succeeded in developing low cost diagnostic kits in Pakistan that would save time and money (Saqlain et al., 2020). Differential diagnosis of symptoms is of crucial importance so that patients having fever and suspected to have COVID-19 could be quarantined and cross infection could be reduced.

\section{THERAPEUTICS, AVAILABLE TREATMENT AND PREDISPOSITION}

Unfortunately to treat COVID-19 associated pathologies, no medicines or antiviral vaccines have yet been approved officially. The only management strategies are the prevention of infection, control methods, and the provision of supplementary oxygen and ventilation when required. It is believed that vaccine would not be available before the year 2021, so the focus now is to reuse the existing drugs and WHO health officials noted efficacy of many drugs against coronavirus infection. Use of antivirals have shown to be affective against this virus as it weakens the ability of the virus to enter cells, stops its multiplication and prevent them from entering healthy cells. Antibiotics have not shown to be beneficial in treating COVID-19 and can be used only in case of bacterial infection. As the disease first appeared in China, so the country started testing different drugs that were already used to treat other diseases like malaria, arthritis drugs, antivirals, blood plasma and its derivatives ( $\mathrm{Li}$ and De Clercq, 2020). An antiviral drug named Favilavir has 
been used in China to treat the patients of COVID-19 as the medicine was developed for the treatment of nose and throat (Li et al., 2020a, c). In a clinical trial of more than 70 patients, this drug proved to be effective in treating symptoms of coronavirus with minimum side effects (Elfiky, 2020). Favilavir has not yet been approved by FDA (Food and Drug Administration) (Li and De Clercq, 2020). In animals, another antiviral drug called Remdesivir showed resistance against two viruses that were similar to SARS-CoV, COVID-19 and MERS Coronavirus (Wang et al., 2020c). Remdesivir is a broad spectrum antiviral drug developed to treat Ebola virus as it acts by prematurely terminating transcription of RNA and inhibits its replication and reproduction (Li et al., 2020b, c). China started its clinical trials in many hospitals in Wuhan and one of the trials has also been approved by FDA in US. In Washington a 35 years old patient was given Remdesivir and was recovered from COVID-19 (Holshue et al., 2020). However, further clinical investigations are required to confirm the efficacy of Remdesivir in treating coronavirus.

Chloroquine and hydroxy-chloroquine are actually used against malaria but is approved by FDA to test it against COVID-19 (Dong et al., 2020; Jie et al., 2020). Researchers have found both the drugs effective against Coronaviruses with hydroxy chloroquine showed relatively higher potency. On the basis of these results, these two drugs are widely used to treat the hospitalized patients in many countries including USA. In a clinical study in China, Chloroquine was tested on 100 patients and showed extraordinary results in inhibiting the pneumonia, improving CT scan findings and shortening the disease span (Zhonghua, 2020; Gao et al., 2020). Another approach suggests the use of prophylactic hydroxylchloroquine treatment to prevent SARS-CoV-2 infection or disease development. A number of clinical trials are underway to assess the prophylactic benefits of hydroxylchloroquine. However, it may lead to life threatening arrhythmias which may be common in patients with preexisting cardiovascular diseases. The corona virus enters into the cell by fusing with lysosomes and endosomes which are intracellular organelles. Hydroxy-chloroquine increases the $\mathrm{pH}$ of theses organelles, reduces binding of SARS-CoV-2 with ACE-2 receptors, disrupts ACE-2 glycosylation and prevents transportation of virus within cells (Offerhaus et al., 2020).

Another medicine Tocilizumab available as Actemra was tested on acute COVID-19 patients and about 95\% patients recovered (Zhang et al., 2020a, b). Darunavir, an anti-retroviral drug studied by Chinese researchers inhibited SARS-CoV-2 infection and replication (Dong et al., 2020). Similarly, an anti-parasitic medicine Ivermectin has also shown efficacy against SARS- CoV-2 infection
(Caly et al., 2020).

Convalescent plasma (CP), having high neutralizing antibody titer from the recovered COVID-19 patients is approved by FDA for the treatment of COVID-19 infection (Chen et al., 2020b). For more than a century, blood plasma therapy has been used for the treatment and control of infectious diseases like Influenza in 1918 and measles in 1930s. Recently it has been used for SARS-CoV, Ebola virus etc. (Van Griensven et al., 2016; Cheng et al., 2005). Blood plasma therapy has been proved effective against SARS epidemic in 2003 (Cheng et al., 2005). Since, SARS and COVID-19 are similar kind of viruses, this therapy is hoped to be effective treatment against SARS-CoV-2 infection. Hospitals in New York City are using blood plasma from the recovered patients as an antidote to the disease (Duan et al., 2020; Jawhara, 2020). However, there are some risks involved in CP therapy i.e. the transmission of blood borne pathogens such as HBV (Hepatitis B), HCV (Hepatitis C) and, HIV (Human Immuno Deficiency Virus) (MacLennan and Barbara, 2006).

In Pakistan blood plasma therapy is in high demand to cure COVID-19 patients due to great surge in number of cases that has overburdened the country's public health care system. Doctors also advised the use of passive immunization, a medical technique that involves administering antibodies from recovered COVID-19 patients to infected individuals. It is specifically used when infection risk is higher and immune system of a person to generate antibodies is low (Anonymous, 2020b). Amid chaotic situation, the blood plasma of recovered patients is being sold in black market to the people who are desperate to find the cure of the disease as CP contains the antibodies that could be a possible treatment for this disease. According to experts, it has turned to a lucrative business for those who see money making opportunity in crisis and also due to the fact that the people have lost their livelihood due to the current coronavirus situation. Ministry of health has advised the public and physicians on the judicious use of blood plasma therapy for coronavirus patients from time to time. The government says that it has set up health centers where it can be donated legally and professionally. The government has designated five hospitals for the purpose of collecting blood plasma in the country. At least, 351 COVID-19 patients have received blood plasma in these centers (Anonymous, 2020c).

Researchers in UK announced that Dexamethasone a "steroid" and anti-inflammatory medicine cuts the risk of death in severely ill coronavirus patients as the WHO has hailed it as "Lifesaving breakthrough". Pakistan health's minister said that the country has ample supply of drugs and it may be included in the standard treatment for COVID-19 patients. It has also been clarified by him that 
it can only be used to treat the patients who are critically ill and require oxygen or ventilation (Anonymous, 2020d).

\section{PREVENTION AND CONTROL OF INFECTION}

Development of vaccine would take time, so for now the most important thing is to follow the safety guidelines provided by WHO such as social distancing, avoiding hand shake, washing hands frequently for 40 seconds and disinfecting homes and working areas (Xiao et al., 2020). As compared to other coronaviruses, SARS-CoV-2 spreads more rapidly and may be life threatening. Its survival in the air is $3 \mathrm{~h}$ and it may stay on plastic, stainless steel, cardboard and copper for $72,48,24$ and $4 \mathrm{~h}$ respectively. It can spread from a person without any obvious symptoms to others. WHO has recommended some of the guidelines to prevent COVID-19 which includes: washing hands frequently specially after in contact with infected person, avoid touching eyes, noses and mouths, covering the mouths and noses during coughing or sneezing, keeping a safe distance of 6 feet from others, wearing of masks and self-quarantine (Jin et al., 2020a, b; Wang et al., 2020c). For health care workers, it is recommended to wear N-95 and FFP3 masks and other protections while treating patients (Wang et al., 2020c). There might be a susceptibility of SARS-CoV-2 to disinfectants like sodium hypochlorite, hydrogen per oxide, ethanol, and phenolic and, ammonium compounds if used as recommended (Rabenau et al., 2005). Wang et al. (2010) reported that there are chances of rapid spread of the virus in extreme weather conditions. Seasonality and latitude also plays an important role in the spread of the disease (Sajadi et al., 2020). Some previous studies also suggested that the predisposing factors of some respiratory diseases are certain climatic conditions (D'Amato et al., 2014). The climatic components for example rainfall, temperature and wind speed may act as a catalyst for interface between humans and COVID-19. There are numbers of factors that affect virus transmission such as infectivity of the virus, defense mechanisms of host, host behavior (Cory, 2015) environmental factors, and population density (Brown et al., 2008). However, there are some evidences that suggest that warmer climate may cause the slow spread of the virus (Wang et al., 2020a, b). It is still not known how SARSCoV-2 interacts with hot weather but the other types of coronaviruses have been reported to spread slowly in warmer climatic conditions.

\section{CHALLENGES AHEAD}

There are no particular medicines or anti-viral drugs available at present to treat coronavirus disease. Therefore, the only way to manage the disease is by symptomatic treatment. Although many drugs are available like lopinavir, remdesivir, arbidol for treating SARS-CoV-2 but none of them is considered as a potential treatment till now (Wang et al., 2020a; Jin et al., 2020a, b). In an era where new kinds of viruses are constantly emerging, the development of antiviral vaccines is a difficult task but is of great importance for human sustenance. The matter became worse when the virus continues to evolve and re-emerge escaping the current therapeutic measures as seen in case of SARS-CoV-2. Since the discovery of first anti-viral drug, some of the drugs were developed to be an effective and safe treatment but none of them proved effective against coronavirus (De Clercq and Li, 2016). Development of effective antiviral medicine is a complex process that involves the screening of the available therapeutic database, present broad spectrum antiviral drugs and even developing new drugs (Zumla et al., 2016). In a systemic analysis, the potential and significant antiviral targets have been identified against COVID-19 like S spike protein of the virus, host cells ACE-2 receptors, RNA genome, moieties like RdRp etc. (Wu et al., 2020). In pre-clinical studies, many small molecules and antiviral drugs have proven to block the activities of COVID-19 and MERS-CoV, but showed meager results in human clinical trials. Since there is a genomic and structural similarity between all the coronaviruses like SARS-CoV-1, MERS$\mathrm{CoV}$, and SARS-CoV-2, repurposing of existing drugs may result in the solution of this pandemic. Some of the new techniques for the prevention and treatment of SARSCoV-2 are: Virus glycoprotein and receptor targeting drugs, mRNA, protease and replicase targeting drugs and antibodies. However, a prolonged period is required for the screening and development of new therapeutic strategies.

In Pakistan, this pandemic has posed serious questions regarding the weak health care system of the country as the number of cases rose to 288,717 in August 2020 as per WHO Situation Report No. 209. Pakistan is a low income country and is vulnerable to SARS-CoV-2, and has a huge population of 197 million (Hayat et al., 2020). Pakistan shares its borders with Iran and China which are pandemic epicenters, so effective strategies and policies are required to control the situation (Saqlain et al., 2020). According to WHO (WHO, 2020b) all the preventive control measures should be taken by the countries to limit the transmission of virus for example by doing awareness campaigns, early detection of virus, adopting quarantine measures and surveillance of the disease. Today this is a major concern besides other challenges of healthcare (Anonymous, 2020e). Pakistan also lacks medical facilities and has to send the suspected samples to China (Khanain, 2020). 
In addition, there are only few quarantine centers with a limited treatment and diagnostic facility (Anonymous, 2020f). The government has to get the testing kits and primers from other countries. By June 2020, the country has many testing centers (Khanain, 2020). Moreover, the availability of facemasks became scarce and costly after pandemic, many equipment and drugs ran short and stockiest started stocking, however, by the action of Government everything went under control. Hospitals are unable to provide required medical facilities. People of Pakistan disregarded the advice of Government and health care officials as a result number of COVID-19 patients increased drastically and the hospitals were overflowed with patients (Kermani, 2020). ICUs were occupied and health care cost increased tremendously (Hashim, 2020). There was shortage of doctors and paramedical staff and they lacked required training regarding pandemic (Jaffery, 2020). Moreover, different drugs like dexamethasone which is considered as helpful in treating COVID-19 patients were not available in pharmacies (Qureshi, 2020). Hence, much more efforts are needed to control the disease as experts fear that if appropriate measures are not taken it would result in catastrophe (Yi et al., 2020). People must follow SOPs given by the Government to overcome this predicament. Many government officials proposed "Herd Immunity" as a solution to this problem, but there are certain ethical and legal challenges requiring people to be immunized through herd immunity. It was proposed that if the virus spreads at a certain rate in Pakistan, people will become immune to it (Anonymous, 2020g). Still, it is not considered by the Government to implement this strategy as it would risk the lives of vulnerable and elderly community (Khan, 2020).

\section{CONCLUSIONS}

COVID-19 is not only a health crisis but also a developmental predicament. It has moved like a wave causing number of deaths and destroying world economies. The exact function and mechanism of the virus is still unknown. Drug development is a challenging but very important task however, many pharmaceutical companies around the world are trying to develop effective medicine or vaccines against the virus. More studies on the biology and structure of the virus are required for vaccine or antiviral drug development. Until then, we must follow all the recommendations given by WHO to prevent the spread and transmission of the disease. In Pakistan, low literacy rate, high population density in the big cities and nonserious attitude of the people in adopting social distancing, wearing masks and personal hygiene have resulted in the massive spread of the virus. The approach of track, test and treat is required to stop the exponential increase in the number of cases.

Statement of conflict of interest

The authors have declared no conflict of interest.

\section{REFERENCES}

Alfaraj, S.H., Al-Tawfiq, J.A., Altuwaijri, T.A. and Memish, Z.A., 2017a. Middle East respiratory syndrome coronavirus and pulmonary tuberculosis coinfection: Implications for infection control. Intervirology, 60: 53-55. https://doi. org/10.1159/000477908

Alfaraj, S.H., Al-Tawfiq, J.A., Alzahrani, N.A., Altwaijri, T.A. and Memish, Z.A., 2017b. The impact of co-infection of influenza A virus on the severity of Middle East respiratory syndrome coronavirus. J. Infect., 74: 521-523. https://doi. org/10.1016/j.jinf.2017.02.001

Ali, I., 2020. Pakistan confirms first two cases of coronavirus. Govt says 'No need to Panic, Dawn available at http://www.dawn.com/news/ amp1536792

Anonymous, 2005. Virus taxonomy. Eighth report of the international committee on the taxonomy of viruses.

Anonymous, 2020a. Herd immunity. Dawn, 10 May, 2020. https://www.dawn.com/news/1555939

Anonymous, 2020b. Passive immunization can treat coronavirus patients, says top hematologist of Pakistan. Bol News. 2020. http://www.bolnews. com/health/2020/03/passive-immunizationcan-treat coronavirus-says-top-hematologist-ofpakistan.

Anonymous, 2020c. Coronavirus in Pakistan: Blood plasma in high demand to cure COVID-19 patients. http://www.dw.com/en/coronaviruspakistan/a-54016553

Anonymous, 2020d. Pakistan mulls using dexamethasone on COVID-19 patients. http://www. aa.com.tr/en/asia-pacific/pakistan-mulls-usingdexamethasone-on-covid-19-patients/1879967

Anonymous, 2020e. UN guidance note on addressing and countering COVID-19 related hate speech. UN office on Genocide Prevention and the responsibility to protect, 11 May 2020.

Anonymous, 2020f. Coronavirus quarantine center with 300 beds established in Islamabad. 92 News HD Plus, 3 March 2020.

Anonymous, 2020g. Herd immunity. Dawn, 10 May, 2020. 
Badawi, A., and Ryoo, S.G., 2016. Prevalence of comorbidities in the Middle East respiratory syndrome coronavirus (MERS-CoV): A systematic review and meta-analysis. Int. J. Infect. Dis., 49: 129-133. https://doi.org/10.1016/j.ijid.2016.06.015

Brown, H.E., Childs, J.E., Diuk-Wasser, M.A. and Fish, D., 2008. Ecologic factors associated with West Nile virus transmission, northeastern United States. Emerg. Infect. Dis., 14: 1539-1545. https:// doi.org/10.3201/eid1410.071396

Caly, L., Druce, J.D., Catton, M.G., Jans, D.A. and Wagstaff, K.M., 2020. The FDA-approved drug ivermectin inhibits the replication of SARS-CoV-2 in vitro. Antivir. Res., pp. 104787. https://doi. org/10.1016/j.antiviral.2020.104787

Cavanagh, D., 1997. Nidovirales: A new order comprising Coronaviridae and Arteriviridae. Arch. Virol., 142: 629-633.

Chan, J.F.W., Yuan, S., Kok, K.H., To, K.K.W., Chu, H., Yang, J., Xing, F., Liu, J., Yip, C.C.Y., Poon, R.W.S. and Tsoi, H.W., 2020. A familial cluster of pneumonia associated with the 2019 novel coronavirus indicating person-toperson transmission: a study of a family cluster. Lancet, 395: 514-523. https://doi.org/10.1016/ S0140-6736(20)30154-9

Chen, L., Xiong, J., Bao, L., and Shi, Y., 2020 b. Convalescent plasma as a potential therapy for COVID-19. Lancet Infect. Dis., 20: 398-400. https://doi.org/10.1016/S1473-3099(20)30141-9

Chen, N., Zhou, M., Dong, X., Qu, J., Gong, F., Han, Y., Qiu, Y., Wang, J., Liu, Y., Wei, Y., Xia, J., Yu, T., Zhang, X., and Zhang, L., 2020a. Epidemiological and clinical characteristics of 99 cases of 2019 novel coronavirus pneumonia in Wuhan, China: a descriptive study. Lancet, 395: 507-513. https://doi. org/10.1016/S0140-6736(20)30211-7

Cheng, Y., Wong, R., Soo, Y.O., Wong, W.S., Lee, C.K., Ng, M.H., Chan, P., Wong, K.C., Leung, C.B., and Cheng, G., 2005. Use of convalescent plasma therapy in SARS patients in Hong Kong. Eur. $J$. Clin. Microbiol. Infect. Dis., 24: 44-46. https://doi. org/10.1007/s10096-004-1271-9

Corman, V., Bleicker, T., Brünink, S., Drosten, C. and Zambon, M., 2020. Diagnostic detection of Wuhan coronavirus 2019 by real-time RT-PCR. Geneva: World Health Organization, January, 13. https:// doi.org/10.2807/1560-7917.ES.2020.25.3.2000045

Cory, J.S., 2015. Insect virus transmission: different routes to persistence. Curr. Opin. Insect Sci., 8: 130135. https://doi.org/10.1016/j.cois.2015.01.007

Cui, J., Li, F. and Shi, Z.L., 2019. Origin and evolution of pathogenic coronaviruses. Nat. Rev. Microbiol., 17: 181-192. https://doi.org/10.1038/s41579-0180118-9

D’Amato, G., Cecchi, L., D'Amato, M. and AnnesiMaesano, I., 2014. Climate change and respiratory diseases. Eur. Respir. Rev., 23: 161-169. https://doi. org/10.1183/09059180.00001714

De Clercq, E. and Li, G., 2016. Approved antiviral drugs over the past 50 years. Clin. Microbiol. Rev., 29: 695-747. https://doi.org/10.1128/CMR.00102-15

de Wit, E., van Doremalen, N., Falzarano, D., and Munster, V.J., 2016. SARS and MERS: Recent insights into emerging coronaviruses. Nat. Rev. Microbiol., 14: 523-534. https://doi.org/10.1038/ nrmicro.2016.81

Dong, L., Hu, S. and Gao, J., 2020. Discovering drugs to treat coronavirus disease 2019 (COVID-19). Drug Discov. Ther, 14: 58-60. https://doi.org/10.5582/ ddt.2020.01012

Duan, K., Liu, B., Li, C., Zhang, H., Yu, T., Qu, J., Zhou, M., Chen, L., Meng, S., Hu, Y. and Peng, C., 2020. Effectiveness of convalescent plasma therapy in severe COVID-19 patients. P. natl. Acad. Sci., 117: 9490-9496. https://doi.org/10.1073/ pnas. 2004168117

Elfiky, A.A., 2020. Anti-HCV, nucleotide inhibitors, repurposing against COVID-19. Life Sci., 248: 117477. https://doi.org/10.1016/j.lfs.2020.117477

Fan, C., Li, K., Ding, Y., Lu, W.L. and Wang, J., 2020. ACE2 expression in kidney and testis may cause kidney and testis damage after 2019-nCoV infection. MedRxiv. https://doi. org/10.1101/2020.02.12.20022418

Gao, J., Tian, Z., and Yang, X., 2020. Breakthrough: Chloroquine phosphate has shown apparent efficacy in treatment of COVID-19 associated pneumonia in clinical studies. Biosci. Trends, 14: 72-73. https://doi.org/10.5582/bst.2020.01047

Guan, W.J., Ni, Z.Y., Hu, Y., Liang, W.H., Ou, C.Q., He, J.X., Liu, L., Shan, H., Lei, C.L., Hui, D., Du, B., Li, L.J., Zeng, G., Yuen, K.Y., Chen, R.C., Tang, C.L., Wang, T., Chen, P.Y., Xiang, J., Li, S.Y., Wang, J., Liang, Z., Peng, Y., Wei, L., Liu, Y., Hu, Y., Peng, P., Wang, J., Liu, J., Chen, Z., Li, G., Zheng, Z., Qiu, S., Luo, J., Ye, C.J., Zhu, S.Y. and Zhong, N.S., 2020. China medical treatment expert group for Covid-19, 2020. Clinical characteristics of coronavirus disease 2019 in China. N. Engl. J. Med., 382: 1708-1720. https:// doi.org/10.1101/2020.02.06.20020974

Guo, Y.R., Cao, Q.D., Hong, Z.S., Tan, Y.Y., Chen, S.D., Jin, H.J., Tan, K.S., Wang, D.Y. and Yan, Y., 2020. 
The origin, transmission and clinical therapies on coronavirus disease 2019 (COVID-19) outbreak, an update on the status. Mil. Med. Res., 7: 1-10. https://doi.org/10.1186/s40779-020-00240-0

Hashim, A., 2020. Pakistan hospitals struggle as coronavirus cases explode. Al Jazeera, pp. 12.

Hayat, K., Rosenthal, M., Xu, S., Arshed, M., Li, P., Zhai, P., Desalegn, G.K. and Fang, Y., 2020. View of Pakistani residents toward coronavirus disease (COVID-19) during a outbreak: A Rapid Online Survey. Int. J. Environ. Res. Publ. Hlth., 17: 3347. https://doi.org/10.3390/ijerph17103347

Holshue, M.L., DeBolt, C., Lindquist, S., Lofy, K.H., Wiesman, J., Bruce, H., Spitters, C., Ericson, K., Wilkerson, S., Tural, A., Diaz, G., Cohn, A., Fox, L., Patel, A., Gerber, S.I., Kim, L., Tong, S., Lu, X., Lindstrom, S. and Pallansch, M.A., 2020. Washington state 2019-nCoV case investigation team 2020. First Case of 2019 Novel Coronavirus in the United States. N. Engl. J. Med., 382: 929936. https://doi.org/10.1056/NEJMoa2001191

Jaffery, R., 2020. Pakistan struggles to fight COVID-19. The Diplomat, 15 April 2020. https://thediplomat. com/2020/04/pakistan-struggles-to-fight-covid-19

Jaillon, S., Berthenet, K. and Garlanda, C., 2019. Sexual Dimorphism in Innate Immunity. Clin. Rev. Allergy Immunol., 56: 308-321. https://doi.org/10.1007/ s12016-017-8648-x

Jawhara, S., 2020. Could Intravenous immunoglobulin collected from recovered coronavirus patients protect against COVID-19 and strengthen the immune system of new patients? Int. J. Mol. Sci., 21: 2272. https://doi.org/10.3390/ijms21072272

Jie, Z., He, H., Xi, H. and Zhi, Z., 2020. Expert consensus on chloroquine phosphate for the treatment of novel coronavirus pneumonia. Zhonghua Jie He He Hu Xi Za Zhi, 43: 185-188.

Jin, Y., Yang, H., Ji, W., Wu, W., Chen, S., Zhang, W. and Duan, G., 2020a. Virology, epidemiology, pathogenesis, and control ofCOVID-19. Viruses, 12: 372. https://doi.org/10.3390/v12040372

Jin, Y.H., Cai, L., Cheng, Z.S., Cheng, H., Deng, T., Fan, Y.P., Fang, C., Huang, D., Huang, L.Q., Huang, Q. and Han, Y., 2020b. A rapid advice guideline for the diagnosis and treatment of 2019 novel coronavirus (2019-nCoV) infected pneumonia (standard version). Mil. Med. Res., 7: 4.

Kermani, S., 2020. Coronavirus: Rumours, fear and rising Covid deaths in Pakistan. BBC News.

Khan, M.S., 2020. Questions about Pakistan's Covid-19 control strategy. The News, 21 June 2020. https://www.thenews.com.pk/tns/detail/674891- questions-about-pakistans-covid-19.

Khanain, W., 2020. Pakistan now equipped to test for novel coronavirus, says PM's aide. Dawn, 12 February 2020.

Kuo, L., Godeke, G.J., Raamsman, M.J., Masters, P.S. and Rottier, P.J., 2000. Retargeting of coronavirus by substitution of the spike glycoprotein ectodomain: Crossing the host cell species barrier. J. Virol., 74: 1393-1406. https://doi.org/10.1128/JVI.74.3.13931406.2000

Lee, N., Chan, P.K.S., Yu, I.T., Tsoi, K.K., Lui, G., Sung, J.J.Y. and Cockram, C.S., 2007. Co-circulation of human metapneumovirus and SARS-associated coronavirus during a major nosocomial SARS outbreak in Hong Kong. J. Clin. Virol., 40: 333337. https://doi.org/10.1016/j.jcv.2007.08.015

Lei, J., Li, J., Li, X. and Qi, X., 2020. CT imaging of the 2019 novel coronavirus (2019-nCoV) pneumonia. Radiology, 295: 18. https://doi. org/10.1148/radiol.2020200236

Lescure, F.X., Bouadma, L., Nguyen, D., Parisey, M., Wicky, P.H., Behillil, S., Gaymard,A., BouscambertDuchamp, M., Donati, F., Le Hingrat, Q., Enouf, V., Houhou-Fidouh, N., Valette, M., Mailles, A., Lucet, J.C., Mentre, F., Duval, X., Descamps, D., Malvy, D., Timsit, J.F. and Yazdanpanah, Y., 2020. Clinical and virological data of the first cases of COVID-19 in Europe: A case series. Lancet. Infect. Dis., 20: 697-706. https://doi.org/10.1016/S14733099(20)30200-0

Li, G. and De Clercq, E., 2020. Therapeutic options for the 2019 novel coronavirus (2019-nCoV). Nat. Rev. Drug Discov., 19: 149-150. https://doi.org/10.1038/ d41573-020-00016-0

Li, H., Wang, Y.M., Xu, J.Y. and Cao, B., 2020 b. Potential antiviral therapeutics for 2019 Novel Coronavirus. Zhonghua jie he he hu xi za zhi Chinese J. Tuberc. Respirat. Dis., 43: E002-E002.

Li, Q., Guan, X., Wu, P., Wang, X., Zhou, L., Tong, Y., Ren, R., Leung, K., Lau, E., Wong, J. Y., Xing, X., Xiang, N., Wu, Y., Li, C., Chen, Q., Li, D., Liu, T., Zhao, J., Liu, M., Tu, W., Feng, Z., 2020 a. Early transmission dynamics in Wuhan, China, of novel coronavirus-infected pneumonia. N. Engl. J. Med., 382: 1199-1207. https://doi.org/10.1056/ NEJMoa2001316

Li, Y. and Xia, L., 2020. Coronavirus disease 2019 (COVID-19): role of chest CT in diagnosis and management. Am. J. Roentgenol., 214: 1280-1286. https://doi.org/10.2214/AJR.20.22954

Li, Z., Wu, M., Guo, J., Yao, J., Liao, X., Song, S., Han, M., Li, J., Duan, G., Zhou, Y. and Wu, 
X., 2020c. Caution on kidney dysfunctions of 2019-nCoV patients. MedRxiv. https://doi. org/10.1101/2020.02.08.20021212

Liu, J., Liao, X., Qian, S., Yuan, J., Wang, F., Liu, Y., Wang, Z., Wang, F.S., Liu, L. and Zhang, Z., 2020. Community transmission of severe acute respiratory syndrome coronavirus 2, Shenzhen, China, 2020. Emerg. Infect. Dis., 26: 1320-1323. https://doi.org/10.3201/eid2606.200239

Lu, C.W., Liu, X.F., and Jia, Z.F., 2020. 2019-nCoV transmission through the ocular surface must not be ignored. Lancet, 395: 39. https://doi.org/10.1016/ S0140-6736(20)30313-5

MacLennan, S. and Barbara, J.A., 2006. Risks and side effects of therapy with plasma and plasma fractions. Best Pract. Res. Clin. Haematol., 19: 169189. https://doi.org/10.1016/j.beha.2005.01.033

Masters, P.S., 2006. The molecular biology of coronaviruses. Adv. Virus Res., 66: 193-292. https:// doi.org/10.1016/S0065-3527(06)66005-3

OCHA, 2020. Pakistan COVID-19 Situation Report No 16, 31 $1^{\text {st }}$ August 2020.

Offerhaus, J.A., Wilde, A.A. and Remme, C.A., 2020. Prophylactic (hydroxy) chloroquine in COVID-19: Potential relevance for cardiac arrhythmia risk. Heart Rhythm., 17: 1480-1486. https://doi. org/10.1016/j.hrthm.2020.07.001

Peiris, J.S.M., Guan, Y. and Yuen, K.Y., 2004. Severe acute respiratory syndrome. Nat. Med., 10: S88-S97. https://doi.org/10.1038/nm1143

Qureshi, Z. 2020. COVID-19: 'Breakthrough' drug dexamethasone running short in Pakistan markets. Gulf News, 19 June 2020. https://gulfnews.com/ world/asia/pakistan/covid-19-breakthroughdrugdexamethasone-running-short-in-pakistanmarkets-1.72136756.

Rabenau, H.F., Kampf, G., Cinatl, J. and Doerr, H.W., 2005. Efficacy of various disinfectants against SARS coronavirus. J. Hosp. Infect., 61: 107-111. https://doi.org/10.1016/j.jhin.2004.12.023

Riou, J. and Althaus, C.L., 2020. Pattern of early human-to-human transmission of Wuhan 2019 novel coronavirus (2019-nCoV), December 2019 to January 2020. Euro. Surveill., 25: 2000058. https:// doi.org/10.2807/1560-7917.ES.2020.25.4.2000058

Sajadi, M.M., Habibzadeh, P., Vintzileos, A., Shokouhi, S., Miralles-Wilhelm, F., and Amoroso, A., 2020. Temperature, humidity, and latitude analysis to estimate potential spread and seasonality of coronavirus disease 2019 (COVID-19). JAMA Netw. Open, 3: e2011834. https://doi.org/10.1001/ jamanetworkopen.2020.11834
Saqlain, M., Munir, M.M., Ahmed, A., Tahir, A.H. and Kamran, S., 2020. Is Pakistan prepared to tackle the coronavirus epidemic? Drug. Ther. Perspect., pp. 1-2. https://doi.org/10.1007/s40267-020-00721-1

Sethuraman, N., Jeremiah, S.S., and Ryo, A., 2020. Interpreting diagnostic tests for SARS-CoV- 2. J. Am. med. Assoc., 323: 2249-2251. https://doi. org/10.1001/jama.2020.8259

Siu, Y.L., Teoh, K.T., Lo, J., Chan, C.M., Kien, F., Escriou, N., Tsao, S.W., Nicholls, J.M., Altmeyer, R., Peiris, J.S.M. and Bruzzone, R., 2008. The M, $\mathrm{E}$, and $\mathrm{N}$ structural proteins of the severe acute respiratory syndrome coronavirus are required for efficient assembly, trafficking, and release of viruslike particles. J. Virol., 82: 11318-11330. https:// doi.org/10.1128/JVI.01052-08

Tang. X., Wu, C., Li, X., Song, Y., Yao, X., Wu, X., Duan, Y., Zhang, H., Wang, Y., Qian, Z., Cui, J. and Lu, J. 2020. On the Origin and Continuing Evolution of SARS-CoV-2. Natl. Sci. Rev., 10.1093/nsr/ nwaa036. https://doi.org/10.1093/nsr/nwaa036

Tipnis, S.R., Hooper, N.M., Hyde, R., Karran, E., Christie, G. and Turner, A.J., 2000. A human homolog of angiotensin-converting enzyme cloning and functional expression as a captopril-insensitive carboxypeptidase. J. biol. Chem., 275: 3323833243. https://doi.org/10.1074/jbc.M002615200

Van Griensven, J., Edwards, T., de Lamballerie, X., Semple, M.G., Gallian, P., Baize, S., Horby, P.W., Raoul, H., Magassouba, N.F., Antierens, A. and Lomas, C., 2016. Evaluation of convalescent plasma for Ebola virus disease in Guinea. $N$. Engl. J. Med., 374: 33-42. https://doi.org/10.1056/ NEJMoa1511812

Wang, G., Minnis, R.B., Belant, J.L. and Wax, C.L., 2010. Dry weather induces outbreaks of human West Nile virus infections. BMC Infect. Dis., 10: 38. https://doi.org/10.1186/1471-2334-10-38

Wang, M., Cao, R., Zhang, L., Yang, X., Liu, J., Xu, M., Shi, Z., Hu, Z., Zhong, W. and Xiao, G., 2020c. Remdesivir and chloroquine effectively inhibit the recently emerged novel coronavirus (2019nCoV) in vitro. Cell. Res., 30: 269-271. https://doi. org/10.1038/s41422-020-0282-0

Wang, P., Anderson, N., Pan, Y., Poon, L., Charlton, C., Zelyas, N., Persing, D., Rhoads, D. and Babcock, H., 2020a. The SARS-CoV-2 outbreak: diagnosis, infection prevention, and public perception. Clin. Chem., 66: 644-651. https://doi.org/10.1093/ clinchem/hvaa080

Wang, W., Tang, J. and Wei, F., 2020b. Updated understanding of the outbreak of 2019 novel 
coronavirus (2019-nCoV) in Wuhan, China. J. med. Virol., 92: 441-447. https://doi.org/10.1002/ jmv.25689

Waris, A., Khan, A.U., Ali, M., Ali, A. and Baset, A., 2020. COVID-19 outbreak: current scenario of Pakistan. New Microbes New Infect., 100681. https://doi.org/10.1016/j.nmni.2020.100681

Whitworth, J., 2020. COVID-19: A fast evolving pandemic. Trans. R. Soc. Trop. Med. Hyg., 114: 241-248. https://doi.org/10.1093/trstmh/traa025

WHO, 2020a. Coronavirus disease 2019 (COVID-19) Situation Report-52.

WHO, 2020b. Coronavirus disease 2019 (COVID-19) Situation Report-209.

Wrapp, D., Wang, N., Corbett, K.S., Goldsmith, J.A., Hsieh, C.L., Abiona, O., Graham, B.S. and McLellan, J.S., 2020. Cryo-EM structure of the 2019-nCoV spike in the prefusion conformation. Science, 367: 1260-1263. https:// doi.org/10.1126/science.abb2507

Wu, C., Liu, Y., Yang, Y., Zhang, P., Zhong, W., Wang, Y., Wang, Q., Xu, Y., Li, M., Li, X., Zheng, M., Chen, L. and Li, H., 2020a. Analysis of therapeutic targets for SARS-CoV-2 and discovery of potential drugs by computational methods. Acta Pharm. Sin. B., 10: 766-788. https://doi.org/10.1016/j. apsb.2020.02.008

Wu, J.T., Leung, K. and Leung, G.M., $2020 \mathrm{~b}$. Nowcasting and forecasting the potential domestic and international spread of the 2019-nCoV outbreak originating in Wuhan, China: A modelling study. Lancet, 395: 689-697. https://doi.org/10.1016/ S0140-6736(20)30260-9

Wu, Z., and McGoogan, J.M., 2020. Characteristics of and important lessons from the coronavirus disease 2019 (COVID-19) outbreak in China: Summary of a report of 72314 cases from the Chinese Center for Disease Control and Prevention. J. Am. med. Assoc., 323: 1239-1242. https://doi.org/10.1001/ jama.2020.2648

Xiang, F., Wang, X., He, X., Peng, Z., Yang, B., Zhang, J., Zhou, Q., Ye, H., Ma, Y., Li, H., Wei, X., Cai, P. and Ma, W.L., 2020. Antibody detection and dynamic characteristics in patients with COVID-19. Clin. Infect. Is: an official publication of the Infectious Diseases Society of America, ciaa461. Advance online publication.

Xiao, Y., Pan, H., She, Q., Wang, F. and Chen, M., 2020. Prevention of SARS-CoV-2 infection in patients with decompensated cirrhosis. Lancet Gastroenterol. Hepatol., 5: 528-529. https://doi. org/10.1016/S2468-1253(20)30080-7
Yang, Y., Lu, Q., Liu, M., Wang, Y., Zhang, Y., Jalali, N., Dean, N., Longini, I., Halloran, M. E., Xu, B., Zhang, X., Wang, L., Liu, W. and Fang, L., 2019. Epidemiological and clinical features of the 2019 novel coronavirus outbreak in China. medRxiv, https://doi. org/10.1101/2020.02.10.20021675

Yi, Y., Lagniton, P.N., Ye, S., Li, E. and Xu, R.H., 2020. COVID-19: What has been learned and to be learned about the novel coronavirus disease. Int. J. biol. Sci., 16: 1753. https://doi.org/10.7150/ ijbs. 45134

Zahariadis, G., Gooley, T.A., Ryall, P., Hutchinson, C., Latchford, M.I., Fearon, M.A., Jamieson, F.B., Richardson, S., Kuschak, T. and Mederski, B., 2006. Risk of ruling out severe acute respiratory syndrome by ruling in another diagnosis: Variable incidence of atypical bacteria coinfection based on diagnostic assays. Can. Respir. J., 13: 17-22. https://doi.org/10.1155/2006/862797

Zhang, N., Jiang, S. and Du, L., 2014. Current advancements and potential strategies in the development of MERS-CoV vaccines. Expert Rev. Vaccines, 13: 761-774. https://doi.org/10.1586/147 60584.2014.912134

Zhang, Q., Wang, Y., Qi, C., Shen, L. and Li, J., 2020 b. Clinical trial analysis of $2019-\mathrm{nCoV}$ therapy registered in China. J. med. Virol., 92: 540-545. https://doi.org/10.1002/jmv.25733

Zhang, T., Wu, Q. and Zhang, Z., 2020a. Probable Pangolin Origin of SARS-CoV-2 Associated with the COVID-19 Outbreak. Curr. Biol., 30: 13461351. https://doi.org/10.1016/j.cub.2020.03.022

Zhang, Y. and $\mathrm{Xu}$, J.M., 2020. Medical diagnosis and treatment strategies for malignant tumors of the digestive system during the outbreak of novel coronavirus pneumonia. Zhonghua zhong liu za zhi (Chinese J. Oncol.), 42: E005-E005.

Zhao, S., Lin, Q., Ran, J., Musa, S. S., Yang, G., Wang, W., Lou, Y., Gao, D., Yang, L., He, D. and Wang, M.H., 2020. Preliminary estimation of the basic reproduction number of novel coronavirus (2019-nCoV) in China, from 2019 to 2020: A data-driven analysis in the early phase of the outbreak. Int. J. Infect. Dis., 92: 214-217. https:// doi.org/10.1101/2020.01.23.916395

Zhonghua J., 2020. Expert consensus on chloroquine phosphate for the treatment of novel coronavirus pneumonia. Chinese J. Tubercul. Respirat. Med., 43.

Zhou, F., Yu, T., Du, R., Fan, G., Liu, Y., Liu, Z., Xiang, J., Wang, Y., Song, B., Gu, X., Guan, L., Wei, Y., Li, H., Wu, X., Xu, J., Tu, S., Zhang, Y., 
Chen, H. and Cao, B., 2020b. Clinical course and risk factors for mortality of adult inpatients with COVID-19 in Wuhan, China: A retrospective cohort study. Lancet, 395: 1054-1062. https://doi. org/10.1016/S0140-6736(20)30566-3

Zhou, P., Yang, X.L., Wang, X.G., Hu, B., Zhang, L., Zhang, W., Si, H.R., Zhu, Y., Li, B., Huang, C.L. and Chen, H.D., 2020a. A pneumonia outbreak associated with a new coronavirus of probable bat origin. Nature, 579: 270-273. https://doi. org/10.1038/s41586-020-2012-7

Zhu, N., Zhang, D., Wang, W., Li, X., Yang, B., Song,
J., Zhao, X., Huang, B., Shi, W., Lu, R., Niu, P., Zhan, F., Ma, X., Wang, D., Xu, W., Wu, G., Gao, G. F., Tan, W. and China Novel Coronavirus Investigating and Research Team. 2020. A Novel Coronavirus from Patients with Pneumonia in China, 2019. N. Engl. J. Med., 382: 727-733. https://doi.org/10.1056/NEJMoa2001017

Zumla, A., Chan, J.F., Azhar, E.I., Hui, D.S. and Yuen, K.Y., 2016. Coronaviruses drug discovery and therapeutic options. Nat. Rev. Drug Discov., 15: 327-347. https://doi.org/10.1038/nrd.2015.37 